\title{
Evaluation of an Infrared Camera Technique for Detecting Mechanically Induced Internal Voids in Syzygium grande
}

\author{
Daniel C. Burcham, Subhadip Ghosh, Leong Eng Choon, and Fong Yok King
}

\begin{abstract}
In order to evaluate a proposed tree diagnostic technique employing infrared cameras, research was conducted to evaluate the effect of internal voids on surface temperature using a thermal photographic instrument. Three axial cylindrical voids of increasing size (Void A, $327 \mathrm{~cm}^{3}$; Void B, $745 \mathrm{~cm}^{3}$; Void C, $1159 \mathrm{~cm}^{3}$ ) were introduced mechanically in $45 \mathrm{~cm}$ long stem sections and exposed to direct sunlight. Subsequently, infrared images were collected from two diametrically opposed sides of the stem sections at regular 30-minute intervals over 150 minutes. The collected images were evaluated visually to compare stem features with observed temperature anomalies, and temperature data was extracted from a vertical transect in the infrared images. The data extracted were compared against a control stem section without defects to determine the independent and combined effects of void size and internal position on surface temperature. Mean relative temperature revealed a significant temperature change in the stems containing mechanical voids compared to the control stem. Significant increases in mean relative temperature were recorded on the stems containing Void A and Void B compared to the control. However, there was no significant change in mean relative temperature on the stem section containing Void C.

Key Words. Infrared Camera; Internal Defects; Syzygium grande.
\end{abstract}

Trees are indispensible elements of urban landscapes and provide numerous, quantifiable environmental, economic, and social benefits (Dwyer et al. 1992; Kuo 2003; Laverne and WinsonGeideman 2003). However, an increase of harm resulting from tree failures in urban areas is becoming an essential concern worldwide. Therefore, tree hazard assessments are a viable and important tree failure risk reduction stratagem. While striving to mitigate risks, arboricultural practitioners have developed numerous precise diagnostic techniques for the assessment of internal structural defects in standing trees, including destructive (Bethge et al. 1996) and nondestructive (Ouis 2003) techniques. The techniques evaluate the condition of wood based on material properties, such as density, stress wave transmission speed, and electrical conductivity (Nicolotti and Miglietta 1998). They provide information on the spatial extent of healthy and decayed wood within a tree stem, and the results inform decisions made on the safety of an individual tree against failure (Mattheck et al. 1993).

In an attempt to advance nondestructive diagnostic testing, Catena et al. (1990) proposed the application of infrared (IR) cameras in tree hazard assessment. The cameras sense long-wave infrared electromagnetic radiation and render temperature measurements along a standard color gradient in a visual image. Catena et al. (1990) reported that internal structural defects decrease the thermal conductive efficiency of the combined cellular elements (e.g., vessel elements, fiber tracheids, parenchyma cells) constituting dicotyledonous tree stems, and this change would produce variation in the bark surface-temperature distribution. Early reports indicated that relatively cooler surface temperatures would reveal a relationship between structural defects and reduced conductive efficiency (Catena and Catena 2008). Tree hazard assessment with an IR camera has several potential benefits, including general, nondestructive, and rapid diagnostic evaluations. The temperature measurements can be captured instantaneously for objects within the camera's field of view, and this permits evaluation of longitudinal wood conditions compared to point- or plane-specific diagnostic evaluation. Current IR camera technology accurately detects $0.05^{\circ} \mathrm{C}$ temperature variation between $6 \mathrm{~mm}^{2}$ surface area units from a distance of $10 \mathrm{~m}$ (NEC 2010). The digital images can be captured and stored in seconds.

Catena and Catena (2000) reported that epiphytic vegetation, condensed bark moisture, and high solar irradiance masked underlying wood temperature values, and these sources of measurement error could impede the identification of structural defects. These conditions occur commonly in tropical environments, while existing studies of IR camera diagnostic assessments have been carried out exclusively in temperate biomes (Catena 2003). These demonstrations of the technique were limited to in-depth case study analysis on a small number of specimens, and the methodology reported relied heavily on visual interpretations of images, followed by broad comparisons with destructively harvested physical sections of trees to confirm accuracy (Catena and Catena 2008). The potential for introduced bias and the limited transferability of these methods likely limits greater professional acceptance and implementation of the technique. With these points in mind, an experiment was designed to evaluate the effect of mechanically introduced voids, serving as simplified analogues of fungal induced cavities, on stem surface temperature using the infrared camera under controlled conditions. In this way, evidence supporting the technique's accuracy would justify further investigations applying the technique under more complex natural conditions. The objectives of the current study were to (1) identify stem morphological features associated with reduced 
bark surface temperature, (2) determine the influence of mechanical void size and position on bark temperature, and (3) evaluate the use of an IR camera in the detection of mechanical voids under equatorial climatic conditions where temperature variations are small (typically between $24^{\circ} \mathrm{C}$ to $34^{\circ} \mathrm{C}$ ) throughout the year.

\section{MATERIALS AND METHODS}

One Syzygium grande (Myrtaceae) was randomly selected from a row of 26 individual trees planted in the roadside verge along Jurong Town Hall Road in Singapore $\left(1^{\circ} 19^{\prime} 53.72^{\prime} \mathrm{N}\right.$, $\left.103^{\circ} 44^{\prime} 24.55^{\prime \prime} \mathrm{E}\right)$. The selected tree $(41.2 \mathrm{~cm} \mathrm{DBH})$ was in healthy condition without internal decay or defects. The stem of the selected tree was harvested into one, two meter segment on March 18, 2010, and transported to a research laboratory.

The stem segment was further sectioned into four equal $45 \mathrm{~cm}$ long sections. The diameter of each section decreased with greater height from the trunk base, measuring $44 \mathrm{~cm}$ at $0.25 \mathrm{~m}, 41.5 \mathrm{~cm}$ at $0.75 \mathrm{~m}, 40.8 \mathrm{~cm}$ at $1.25 \mathrm{~m}$, and $37.5 \mathrm{~cm}$ at $1.75 \mathrm{~m}$. Relatively greater diameter at the trunk base was caused by trunk taper and buttress root formations, the former contributing to even circumferential expansion and the latter causing circumferential undulations. The average bark thickness, measured on all of the exposed ends of the cut sections, was $1.2 \mathrm{~cm}$. An identical mechanical void was created in three sections and denoted as Void A. The cylindrical void was enlarged subsequently to produce Void B and Void C (Table 1). The mechanical voids were oriented longitudinally $1 \mathrm{~cm}$ interior to the vascular cambium on the east stem aspect (Figure 1). One stem section without a void served as the control for the study. The control section and the three sections with Void A were then exposed to direct sunlight for four hours at midday. The stems were oriented with the east stem aspect facing the $90^{\circ}$ azimuth, and the cut surface proximal to the root collar was placed downward. The stems were subsequently moved to a covered, shaded location for evaluation with an IR camera.

Infrared images were collected with a Thermoteknix VisIR 640 IR camera (Cambridge, UK) calibrated using ambient tem-

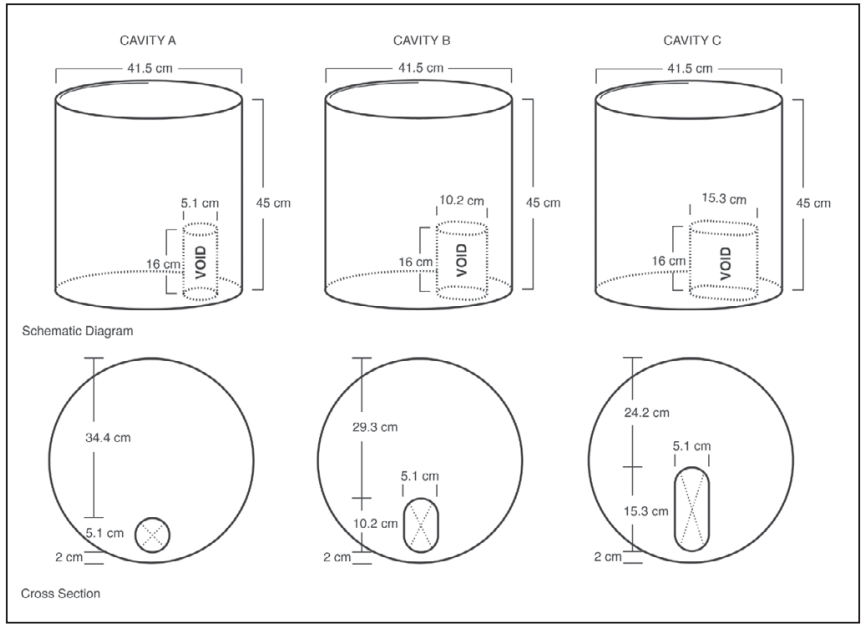

Figure 1. Mechanical voids were introduced incrementally in a radial direction towards the pith at a constant depth of $16 \mathrm{~cm}$ before exposure. Following exposure, infrared images of the stem surface were collected from two perspectives, diametrically opposed, in line with the radius occupied by the void and corresponding with the stem surfaces exposed to the east and west cardinal directions. perature and emissivity values prior to evaluation. Two IR images were captured for each stem section at a distance of one meter. One image was collected by directly focusing at the trunk surface concealing the underlying mechanical void (east aspect) and one additional image was captured of the stem surface directly opposite (west aspect). The depth of the voids, when viewed from these evaluation aspects, varied among treatments (Figure 1). The east aspect received greater amounts of direct solar irradiance from primary exposure during the diurnal solar cycle.

Table 1. Mechanical void dimension, volume, and stem cross-sectional area in cut sections of Syzygium grande.

\begin{tabular}{llll}
\hline Treatment & $\begin{array}{l}\text { Dimension } \\
(\mathrm{cm})\end{array}$ & $\begin{array}{l}\text { Volume } \\
\left(\mathrm{cm}^{3}\right)\end{array}$ & $\begin{array}{l}\text { Cross-sectional } \\
\text { area }\left(\mathrm{cm}^{2}\right)\end{array}$ \\
\hline Control & $0 \times 0 \times 0$ & 0 & 0 \\
Void A & $5.1 \times 5.1 \times 16$ & 327 & 20 \\
Void B & $10.2 \times 5.1 \times 16$ & 745 & 46 \\
Void C & $15.3 \times 5.1 \times 16$ & 1159 & 72 \\
\hline
\end{tabular}

The images were captured regularly at 30-minute intervals for 150 minutes. Atmospheric conditions were recorded hourly during the four-hour time period of stem exposure and subsequent evaluation period, including ambient temperature $\left({ }^{\circ} \mathrm{C}\right)$, relative humidity $(\%)$, and solar irradiance $\left(\mathrm{W} / \mathrm{m}^{2}\right)$. The experiment was repeated with Void B and, subsequently, Void C, on separate days. In total, the experiment contained three factors at different levels (void size ${ }^{4}$ $\times$ aspect $^{2} \times$ time $^{6}$ ). Each treatment combination was performed in triplicate. At the study's conclusion, all stem sections were dissected with a chainsaw to verify the absence of internal defects. The sections were bisected longitudinally, cut into cross sections at $10 \mathrm{~cm}$ intervals, and visually inspected for internal defects.

All thermal images were processed using the TherMonitor ${ }^{\circledR}$ Reporter System (Thermoteknix 2001) after field data collection. An initial visual comparison of the IR images in time-series was performed to identify and examine surface temperature anomalies qualitatively. In qualitative visual examination, relatively dissimilar regions of temperatures in the images were compared

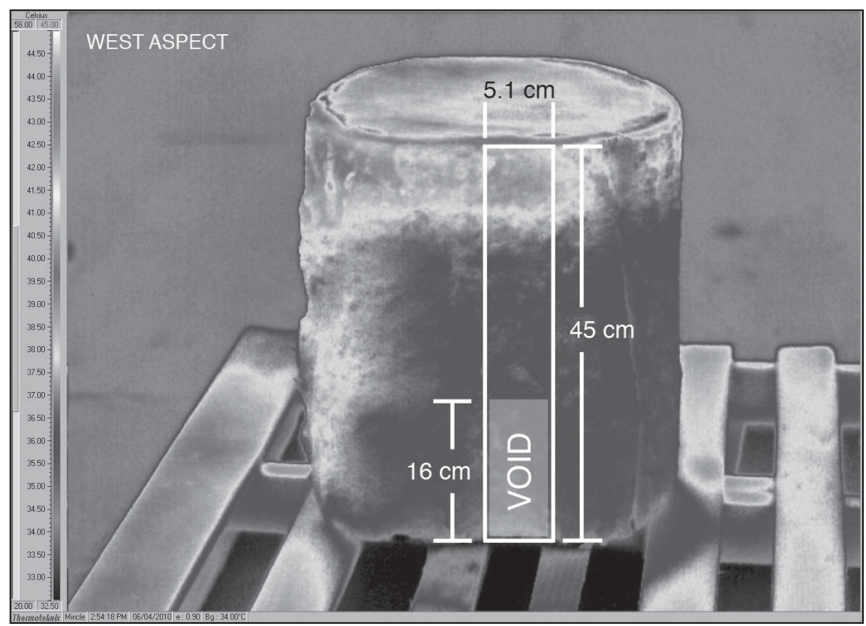

Figure 2. A rectangular transect was imposed onto each infrared image to demarcate the boundary of temperature values extracted for quantitative analysis. The transect was positioned on the bark surface immediately above the underlying, concealed void on both aspects. 
with stem morphological features, and the consistent association of specific features with temperature anomalies was recorded.

Temperature measurements were subsequently extracted from the IR images along a longitudinal transect measuring $5.1 \mathrm{~cm}(\mathrm{w}) \times 45 \mathrm{~cm}(\mathrm{~h})$, positioned central horizontally across each visible stem section (Figure 2).

\section{Statistical Analysis}

The independent and combined effects of void treatments and evaluation aspect on surface temperature were determined using analysis of variance (ANOVA) in R 2.5.0 (R Development Core Team 2006). The void and evaluation aspect effects were evaluated solely within treatments in order to maintain sufficient control of variable atmospheric inputs. Statistical representation of surface temperature was derived using three formulas, including the mean temperature $\left(1 / n \cdot \sum \mathrm{T}_{i}\right)$, mean relative temperature according to Bellett-Travers and Morris (2010) $\left[1 / n \cdot \sum\left(\mathrm{T}_{i}-\mathrm{T}_{\min } /\right.\right.$ $\left.\left.\mathrm{T}_{\max }-\mathrm{T}_{\min }\right)\right]$, and mean normalized temperature $\left[1 / n \cdot \sum\left(\mathrm{T}_{i}-\mathrm{T}_{\mathrm{amb}} /\right.\right.$ $\left.\mathrm{T}_{\mathrm{amb}}\right)$ ], to compare prospective methods of quantitative analysis. In these formulas, $n$ symbolizes the total number of temperature readings, $\mathrm{T}_{i}$ represents a particular temperature value, $\mathrm{T}_{\min }$ stands for the minimum temperature, $\mathrm{T}_{\max }$ stands for the maximum temperature, and $\mathrm{T}_{\text {amb }}$ signifies the ambient temperature. Mean relative temperature depicts the position of the mean between the minimum and maximum exhibited surface temperature on a scale ranging between zero and one. Mean normalized temperature is the mean of the individual temperature values normalized by the ambient temperature reading at the time of image collection. Post-hoc comparisons of means were performed using Tukey's multiple comparisons of means $(\alpha=0.05)$. Variances were checked by plotting residual versus fitted values to confirm the homogeneity of the data. No transformations were necessary.

\section{RESULTS}

Experimental treatments were executed over three 6.5 hour periods during a three-week timeframe, and the climatic con-

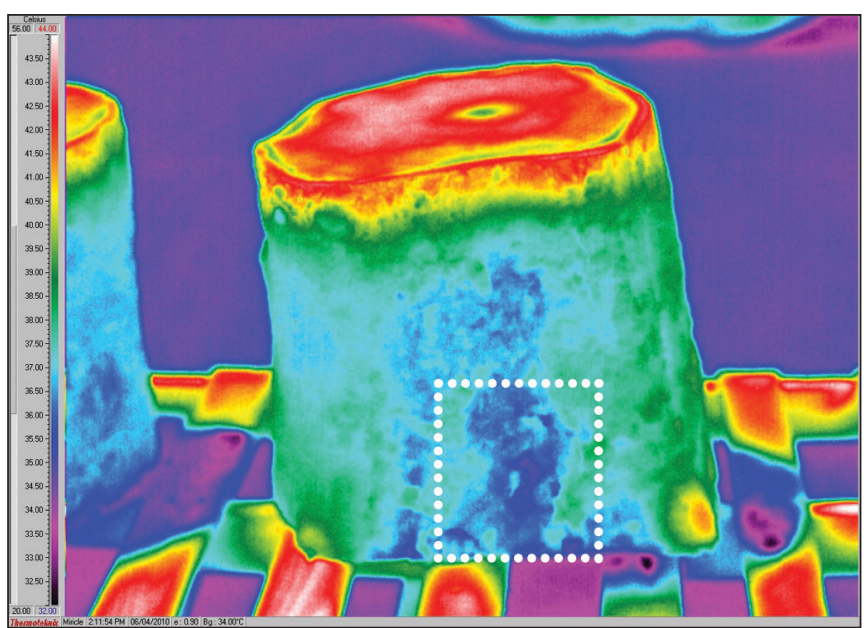

Figure 3. Elliptically cylindrical stems with concave surface undulations showed lower surface temperature values within the depressed areas (white box). The temperature range visualized in this infrared image spans $32^{\circ} \mathrm{C}$ to $44^{\circ} \mathrm{C}$, and the color scale (left) shows the corresponding temperature values represented by each color. ditions varied among treatment dates (Table 2). The mean ambient temperature decreased $4.2 \%\left(1.5^{\circ} \mathrm{C}\right)$ between the first two treatment periods and decreased $0.3 \%\left(0.1^{\circ} \mathrm{C}\right)$ between the second two treatment periods. The mean relative humidity increased $11 \%$ between the first two treatment periods and decreased $39.8 \%$ between the second two treatment periods. On average, the bark temperatures recorded were $1.6^{\circ} \mathrm{C}$ warmer than the average ambient air temperature, irrespective of the time of evaluation, after being exposed to four hours of solar irradiance.

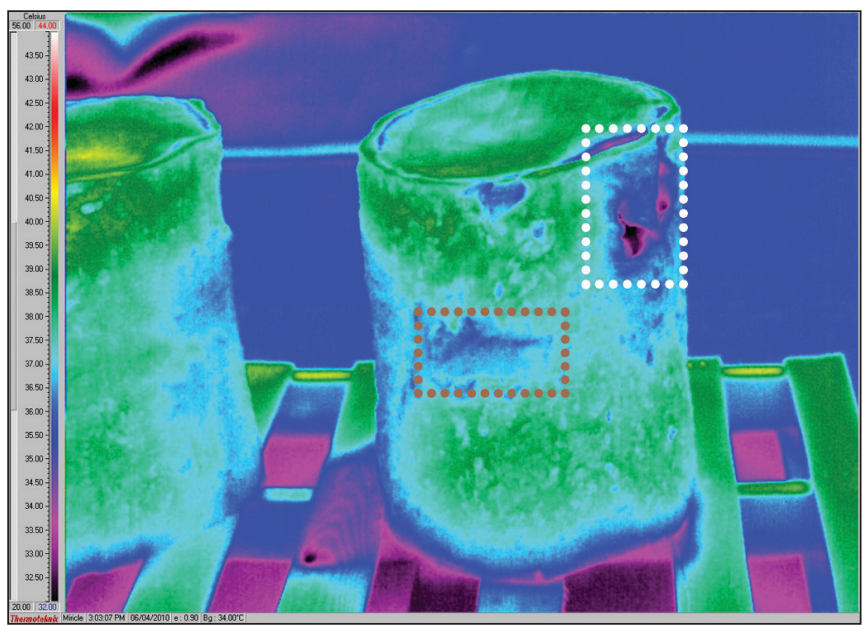

Figure 4. Superficial defects on the trunk, including abrasions (brown box) and detached bark (white box), were consistently associated with lower surface temperatures.

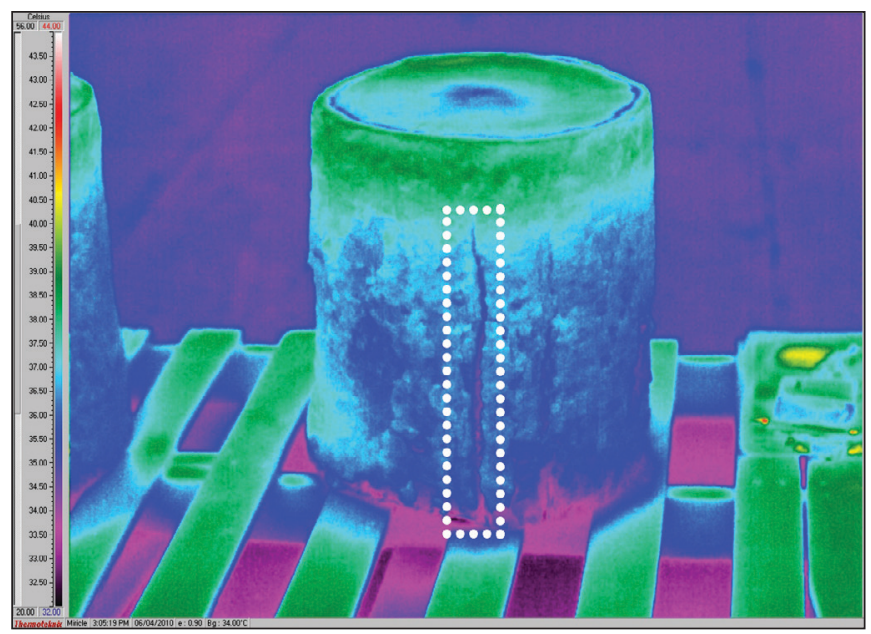

Figure 5. Bark cracks not extending into the stem were related to lower surface temperatures (white box).

Qualitative comparison of the IR images revealed several stem morphological features associated with surface temperature anomalies. Stem geometric features and bark defects appeared to contribute significantly to temperature reductions on multiple occasions. Geometric deviations from a right circular cylinder towards an elliptic cylinder with one or more concave undulations were associated with bark temperature reductions (Figure 3). Abrasions, detached bark, and cracks were also associated with temperature reductions (Figures 4; Figure 5). 
The mean and mean normalized temperatures calculated from the extracted vertical transects did not reveal any relationship between mechanical voids and surface temperature. The average surface temperature observed above the mechanical voids was $0.1^{\circ} \mathrm{C}$ higher than the control stem sections. Mean relative temperature was the only statistic demonstrating a relationship between the voids and surface temperature. Statistical analysis of surface temperature revealed that mean relative temperature is a function of both void size and evaluation aspect if considered independently $(P<0.05)$, but without interaction effects for the first two treatments. The independent effect of void size on mean relative temperature was not found in the third treatment.

Comparison of the mean relative temperatures recorded during each treatment, independent of evaluation aspect, revealed significant changes in surface temperature between stems containing the first two void sizes and the control stem section. Post-hoc comparison revealed a significant $(P<0.05)$ change in the mean relative temperature above Void $\mathrm{A}$ and Void B compared to the respective control stems. The mean relative temperature exhibited above Void A and Void B was $0.04^{\circ} \mathrm{C}$ and $0.08^{\circ} \mathrm{C}$ higher, respectively, compared to the control stem section. No significant change in mean relative temperature compared to the control was found above Void C.

A significant $(P<0.05)$ change in surface temperature between each individual aspect above Void $\mathrm{B}$ and its corresponding aspect on the control stem section was also discovered. The mean relative temperatures observed above the individual east and west aspects were $0.08^{\circ} \mathrm{C}$ and $0.07^{\circ} \mathrm{C}$ higher, respectively, compared to the corresponding aspect on the control stem section (Table 3).

Table 2. Mean atmospheric conditions during the four-hour period of experimental stem exposure.

\begin{tabular}{lccc}
\hline Date & $\begin{array}{c}\text { Temperature } \\
\left({ }^{\circ} \mathrm{C}\right)\end{array}$ & $\begin{array}{c}\text { Relative Humidity } \\
(\%)\end{array}$ & $\begin{array}{c}\text { Irradiance } \\
\left(\mathrm{W} / \mathrm{m}^{2}\right)\end{array}$ \\
\hline April 06, 2010 & 35.2 & 54.4 & 895.8 \\
April 12, 2010 & 33.7 & 65.4 & 769.3 \\
April 19, 2010 & 33.6 & 25.6 & 797.3 \\
\hline
\end{tabular}

A comparison of the individual three statistics representing surface temperatures revealed diverse alterations of each statistic across the three days of the experiment. The mean temperature decreased sequentially among treatments. Mean relative temperature increased between the first two treatments and decreased between the second two treatments. Mean normalized temperature, contrastingly, increased sequentially among the treatments performed on separate days (Table 3).

\section{DISCUSSION}

Variable weather conditions were experienced during each of the three treatments, and the disparity in weather conditions prohibited straightforward comparisons among treatments performed under dissimilar climatic conditions. The variation in ambient temperature and irradiance altered the collective heat input during stem exposure, and the surface temperature distributions more closely reflected variability in atmospheric conditions among treatment periods. Therefore, comparisons made in this experiment were exclusively between the treatment and control stem section temperatures observed on the same day in order to maintain sufficient control. Similar attempts at comparisons may benefit from a stringent assurance that evaluations take place under nearly identical atmospheric conditions.

Qualitative visual evaluation revealed that depressed surfaces, particularly on stem geometries deviating from a right circular cylinder, and external bark defects were visibly associated with temperature reductions (Figure 3; Figure 4; Figure 5). The physical characteristics of these features likely altered the rate of external thermodynamic processes (e.g., solar irradiation, convective heat exchange, infrared radiation exchange) in comparison with surrounding tissue (Potter and Andresen 2002). Physical disruption of the bark, in particular, may have hastened drying and reduced its thermal conductivity, thereby lowering the efficiency of heat transfer outward from the wood. Hunt et al. (2008) reported lower thermal conductivity values, across a range of wood densities, in zero percent moisture compared with fully saturated wood conditions. Collectively, alterations in the rate

Table 3. Surface temperature measurements for all experimental treatments. Note: Significant change in surface temperature is indicated by an asterisk $\left(^{*}\right)(P<0.05)$. Dates are for the 2010 -year.

\begin{tabular}{|c|c|c|c|c|}
\hline Treatment and Aspect & Date & Mean Absolute Temperature $\left({ }^{\circ} \mathrm{C}\right)$ & Mean Relative Temperature $\left({ }^{\circ} \mathrm{C}\right)$ & Mean Normalized Temperature $\left({ }^{\circ} \mathrm{C}\right)$ \\
\hline \multicolumn{5}{|l|}{ Treatment 1} \\
\hline Void A & April 06 & 36.8 & $0.60 *$ & -0.039 \\
\hline East & April 06 & 37.4 & 0.64 & -0.024 \\
\hline Control & April 06 & 36.7 & 0.56 & -0.043 \\
\hline East & April 06 & 37.8 & 0.61 & -0.014 \\
\hline West & April 06 & 35.6 & 0.51 & -0.072 \\
\hline \multicolumn{5}{|l|}{ Treatment 2} \\
\hline Void B & April 12 & 36.0 & $0.62 *$ & -0.036 \\
\hline East & April 12 & 36.1 & $0.64 *$ & -0.032 \\
\hline West & April 12 & 35.8 & $0.60 *$ & -0.040 \\
\hline Control & April 12 & 35.7 & 0.54 & -0.042 \\
\hline East & April 12 & 35.8 & 0.56 & -0.040 \\
\hline West & April 12 & 35.7 & 0.53 & -0.043 \\
\hline \multicolumn{5}{|l|}{ Treatment 3} \\
\hline Void C & April 19 & 34.4 & 0.54 & 0.025 \\
\hline East & April 19 & 34.3 & 0.53 & 0.021 \\
\hline Control & April 19 & 34.4 & 0.53 & 0.025 \\
\hline East & April 19 & 34.6 & 0.51 & 0.032 \\
\hline West & April 19 & 34.2 & 0.55 & 0.018 \\
\hline
\end{tabular}


of these thermodynamic processes could provide an explanation for the temperature reductions associated with external defects.

Quantitative analysis exposed uneven representation of surface temperature by the three evaluated statistics. Mean temperature and mean normalized temperature values did not show a significant change in temperature compared to the control, and these statistics belied any relationship between the internal defects and surface temperatures. The values provided by these two statistics gave a measurement of central tendency for the temperature range exhibited.

Mean relative temperatures calculated from the first two treatments, contrastingly, showed that the mechanical voids had a significant $(P<0.05)$ effect on surface temperature. This statistic represents surface temperatures independent of the absolute temperature values, and it could prove particularly useful while making comparisons among images captured on various dates and times.

The mean relative temperatures recorded were higher compared to the control stem sections and this is a divergence from earlier reported findings of comparatively lower surface temperatures above structural discontinuities (Catena 2003). The discrepancy in results may be caused by the absence of active water movement within the stem sections obtained for the study. Water movement through the vascular system could alter heat energy along a living tree stem, but the effects of this process on the axial surface temperature gradient are not well understood (Potter and Andresen 2002). The largest mechanical void, Void C, occupying $1.9 \%$ of total volume, did not exhibit mean relative temperature values significantly different compared to the control.

A significant change in mean relative temperature was also discovered on the two separate evaluation aspects above Void B, but this temperature difference was observed only once while comparing the evaluation aspects independently. There was no evidence indicating that the internal position of the artificial defect, segregated within two evaluation aspects in this experiment, had any effect on surface temperature distributions compared to the control. Still, this basic comparison does not sufficiently demonstrate that internal voids located immediately beneath the trunk surface have a similar effect on surface temperature compared to those located near the center of the stem. In order to circumvent uncertainty related to irregular internal positions, a circumferential average of exhibited temperatures may increase the technique's sensitivity and subsequent ability to identify internal anomalies. This circumferential surface temperature average may comprise sufficient values so as to preclude any consideration of void depth. This method may facilitate more straightforward identification of internal voids, but it is unclear how this would affect any methodological sensitivity in measuring the amount of degraded tissue.

Further development of image collection, data processing, and quantitative analysis methodologies will be required to achieve a diagnostic technique with reliable consistency. The selective discovery of a relationship between internal mechanical voids and surface temperature is a small positive affirmation of the technique's foundation, and further development of the analytical methods may provide the substantial improvement required for arboricultural implementation. However, it is not possible to directly translate results obtained in this study to field applications of the technique. The typical features of partially decayed wood, including changes in cationic concentrations and gradual decomposition of cellulose and lignin, were not replicated by the introduced mechanical voids (Jellison et al. 1997; Schwarze et al. 1999).
Additionally, the mechanical voids did not accurately replicate the features typical of reaction zone boundaries, including suberized tissue and phenolic infusions (Pearce and Woodward 1986).

\section{CONCLUSIONS}

In this study, the IR camera diagnostic technique was evaluated using tree sections containing mechanically induced voids. After field image collection, the raw temperature data was extracted for analysis with minimal post-processing, and the mechanical voids had an inconsistent effect on surface temperature distributions. The mean relative temperatures showed that the two smaller voids (Void A and Void B) had a significant effect but the largest void (Void C) did not have a significant effect. However, the results of this study should be interpreted with reference to the void sizes evaluated. The sizes created in this study were small, occupying between $1.5 \%$ and $5.4 \%$ total cross-sectional area of the stem, and a fungal induced cavity of this size will not frequently substantiate great concern during tree risk assessments. The mean relative temperature represented the data comparably better than mean normalized temperature for this purpose, and this statistic should be preferentially evaluated in similar applications.

In order to further corroborate the findings of this study, future research is needed to clarify the effect of fungal induced cavities on surface temperature distributions and any diurnal variation in this relationship. The effects of active fungal decay, wood anatomy changes, metabolite status, and translocation through the vascular system on surface temperature should be systematically evaluated to characterize the precise limitations of this technique. Moreover, further analytical methods referencing the relative spatial extent of the temperature values should also be assessed to assist in isolating specific areas of concern on the trunk.

Acknowledgments. The authors would like to thank Ms. Phyllis $\mathrm{Ng}$ Qianyu and Ms. Jackeline Tay Jit Ling for their hard work and persistence creating artificial voids. This project was made possible through funding provided by the National Parks Board of Singapore.

\section{LITERATURE CITED}

Bellett-Travers, M., and S. Morris. 2010. The relationship between surface temperature and radial wood thickness of twelve trees harvested in Nottinghamshire. Arboricultural Journal 33:15-26.

Bethge, K., C. Mattheck, and E. Hunger. 1996. Equipment for detection and evaluation of incipient decay in trees. Arboricultural Journal 20:13-37.

Catena, A. 2003. Thermography reveals hidden tree decay. Arboricultural Journal 27:27-42.

Catena, A., and G. Catena. 2000. Ricerche per la conservazione e la gestione del verde urbano a Roma: l'esempio di Villa Sciarra. Thesis.

Catena, A., and G. Catena. 2008. Overview of thermal imaging for tree assessment. Arboricultural Journal 30:259-270.

Catena, G., L. Palla, and M. Catalano. 1990. Thermal infrared detection of cavities in trees. European Journal of Forest Pathology 20:201-210.

Dwyer, J.F., E.G. McPherson, H.W. Schroeder, and R.A. Rowntree. 1992. Assessing the benefits and costs of the urban forest. Journal of Arboriculture 18:227-234.

Hunt, J.F., H. Gu, and P.K. Lebow. 2008. Theoretical thermal conductivity equation for uniform density wood cells. Wood and Fiber Science 40(2): 167-180. 
Jellison, J., J. Connolly, B. Goodell, B. Doyle, B. Illman, F. Fekete, and A. Ostrofsky. 1997. The role of cations in the biodegradation of wood by the brown rot fungi. International Biodeterioration \& Biodegradation 39(2-3): 165-179.

Kuo, F.E. 2003. The role of arboriculture in a healthy social ecology. Journal of Arboriculture 29(3):148-155.

Laverne, R.J., and K. Winson-Geideman. 2003. The influence of trees and landscaping on rental rates at office buildings. Journal of Arboriculture 29(5):281-290.

Mattheck, C., K. Bethge, and D. Erb. 1993. Failure criteria for trees. Arboricultural Journal 17:201-209.

NEC. 2010. H2640 User Manual. NEC Avio Infrared Technologies Co., Limited, Tokyo.

Nicolotti, G., and P. Miglietta. 1998. Using high-technology instruments to assess defects in trees. Journal of Arboriculture 24:297-302.

Ouis, D. 2003. Non-destructive techniques for detecting decay in standing trees. Arboricultural Journal 27:159-177.

Pearce, R.B., and S. Woodward. 1986. Compartmentalization and reaction zone barriers at the margin of decayed sapwood in Acer saccharinum L. Physiological Plant Pathology 29(2):197-216.

Potter, B.E., and J.A. Andresen. 2002. A finite-difference model of temperatures and heat flow within a tree stem. Canadian Journal of Forest Research 32:548-555.

R Development Core Team. 2006. A language and environment for statistical computing. Vienna, R Foundation for Statistical Computing.

Schwarze, F.W.M.R., D. Lonsdale, and S. Fink. 1999. Soft rot and multiple T-branching by the basidiomycete Inonotus hispidus in ash and London plane. Mycological Research 99(7):813-820.

Thermoteknix. 2001. TherMonitor ${ }^{\circledR}$ Reporter System User Manual. Thermoteknix Systems Limited, Cambridge, England.

Daniel C. Burcham (corresponding author)

Centre for Urban Greenery and Ecology

National Parks Board

Singapore 259569

daniel_burcham@nparks.gov.sg

Subhadip Ghosh

Centre for Urban Greenery and Ecology

National Parks Board

Singapore 259569

Leong Eng Choon

School of Civil and Environmental Engineering

Nanyang Technological University

Singapore 639798

Fong Yok King

Centre for Urban Greenery and Ecology

National Parks Board

Singapore 259569
Résumé. Afin d'évaluer une technique proposée de diagnostic de l'arbre au moyen de caméras infrarouges, une recherche a été menée pour évaluer l'effet des vides internes sur la température à la surface au moyen d'un instrument de photographie thermique. Trois cylindres axiaux de vide - vide A, $237 \mathrm{~cm}^{3}$; vide $\mathrm{B}, 745 \mathrm{~cm}^{3} ; 1159 \mathrm{~cm}^{3}$ - ont été introduits mécaniquement dans des sections de tige de $45 \mathrm{~cm}$ de longueur qui furent exposées directement au soleil. Subséquemment, des images infrarouges ont été prises à partir de deux faces diamétralement opposées de chacune des sections de tige sur une période totale de 150 minutes à intervalles de 30 minutes. Les images recueillies ont été évaluée visuellement par comparaison entre ces dernières et les anomalies de températures observées, et des données ont été extraites à partir d'un transect vertical sur les images infrarouges. Les données extraites ont été comparées par rapport à une tige contrôle sans défaut, le tout afin de déterminer les effets combinés et indépendants de la dimension du vide et de sa position par rapport à la température en surface. La température relative moyenne a permis de révéler un changement significatif de température dans les tiges contenant des vides mécaniques comparativement à la tige contrôle. Des accroissements significatifs de température relative moyenne ont été enregistrés dans les tiges contenant les vides $\mathrm{A}$ et $\mathrm{B}$ comparativement à la tige-témoin. Cependant, il n'y avait pas de changement significatif dans la température relative moyenne dans la section de tige contenant le vide $\mathrm{C}$.

Zusammenfassung. Um eine Baumdiagnose-Technik mittels InfrarotKamera zu testen, wurde ein Versuch durchgeführt, der den Einfluss von internen Hohlräumen auf die Oberflächentemperatur durch den Einsatz eines thermischen, photographischen Instruments messen soll. Drei axiale, zylindrische Hohlräume mit wachsender Größe (Hohlraum 1: 327 $\mathrm{cm}^{3}$, Hohlraum 2: $745 \mathrm{~cm}^{3}$, Hohlraum 3: $1159 \mathrm{~cm}^{3}$ ) wurden mechanisch in $45 \mathrm{~cm}$ lange Stammstücke erzeugt und dem direkten Sonnenlicht ausgesetzt. Anschließend wurden Infrarot-Aufnahmen von zwei diametral entgegengesetzten Seiten der Stammabschnitte in regelmäßigen 30 minütigen Intervallen über einen Gesamtzeitraum von 150 Minuten gesammelt. Die gesammelten Aufnahmen wurden visuell bewertet, um die Stammeigenschaften mit den beobachteten Temperaturanomalien zu vergleichen. Die Temperaturdaten wurden aus einer vertikalten Transsektion in den Infrarot-Bildern extrahiert. Die extrahierten Daten wurden mit Daten von einem Kontrollstamm ohne Defekte verglichen, um den unabhängigen und den kombinierten Effekt der Hohlraumgröße und der internen Position auf die Oberflächentemperatur zu bestimmen. Die mittlere relative Temperaturkurve zeigte einen signifikanten Temperaturwechsel in den Stämmen, die mechanische Hohlräume enthielten, im Vergleich zu den Kontrollstämmen. Signifikante Anstiege in der mittleren relativen Temperatur im Vergleich zu den Kontrollstämmen wurden in den Stämmen mit den Hohlräumen 1 und 2 gemessen. Dennoch gab es keinen signifikanten Anstieg der mittleren Temperatur bei Stämmen mit dem Hohlraum 3.

Resumen. Se realizó una investigación con el fin de evaluar una técnica de diagnóstico del árbol empleando cámaras infrarrojas para valorar el efecto de las cavidades internas en la temperatura superficial usando un instrumento térmico fotográfico. Se introdujeron mecánicamente tres piezas cilíndricas en el eje axial del árbol (Espacio A, $327 \mathrm{~cm} 3$, Espacio B, $745 \mathrm{~cm} 3$, Espacio C, $1159 \mathrm{~cm} 3$ ) en secciones de $45 \mathrm{~cm}$ de longitud y expuestos a la luz directa del sol. Subsecuentemente, las imágenes infrarrojas fueron colectadas de dos lados diametralmente opuestos de las secciones del tallo a intervalos regulares de 30 minutos en 150 minutos. Las imágenes colectadas fueron evaluadas visualmente para comparar las características del tallo con las temperaturas observadas, y los datos de temperatura fueron extraídos de un transecto en imágenes infrarrojas. Los datos extraídos fueron comparados contra secciones del tallo de control sin defectos para determinar los efectos independientes y combinados del tamaño de la cavidad y la posición interna sobre la temperatura superficial. La temperatura media relativa reveló un cambio significante en temperatura en los tallos con cavidades mecánicas comparados con los controles. Los incrementos significativos en la media relativa de temperatura fueron registrados en los tallos con espacio A y espacio B comparados con los controles. Sin embargo, no hubo cambio significativo en la temperatura media relativa registrada en los tallos con los espacios A y B comparados con el control. 